\title{
Naive Bayes Dalam Menentukan Penerima Bantuan Langsung Tunai
}

\author{
Indri Arfanda ${ }^{1}$, William Ramdhan ${ }^{2 *}$, Riki Andri Yusda ${ }^{3}$ \\ ${ }^{1,2}$ Program Studi Sistem Informasi Royal, Indonesia \\ ${ }^{3}$ Program Studi Teknik Komputer Royal, Indonesia \\ Email: ${ }^{1}$ Indri_Arfanda@gmail.com, ${ }^{2}$ william.ramdhan052@gmail.com, ${ }^{3}$ rikiandriyusda@gmail.com
}

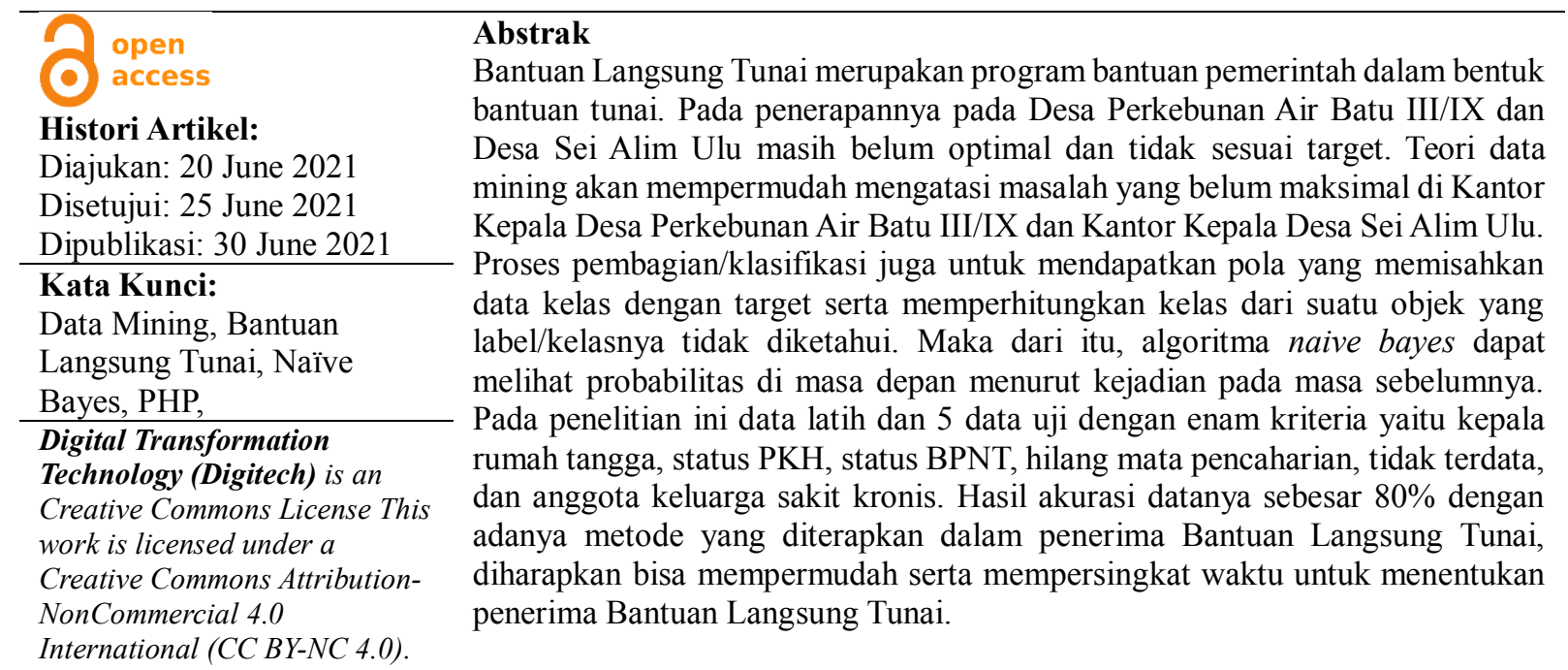

\section{PENDAHULUAN}

Semakin laju pertumbuhan teknologi di era industri 4.0, manusia dituntut untuk berfikir bagaimana cara cepat dan tepat dalam menciptakan suatu sarana yang nantinya akan membantu mempermudah pekerjaan manusia.Masalah ekonomi juga semakin hari semakin menjadi perhatian. Pandemi yang tak kunjung pergi berpengaruh pada perekonomian masyarakat dunia. Dampak sosial dan ekonomi yang diakaibatkan pandemi Covid-19 sangat berpengaruh pada tingkat kesejahteraan masyarakat.

Kemiskinan merupakan sebuah masalah yang amat serius yang masih dihadapi oleh beberapa negara di dunia. Oleh karena hal itu, maka pemerintah membuat kebijakan ataupun program untuk menanggulangi masalah tersebut. Salah satu dari sekian banyak program tersebut adalah Bantuan Langsung Tunai (BLT). Bantuan Langsung Tunai (BLT) dapat dipahami sebagai pemberian sejumlah uang (dana tunai) kepada masyarakat miskin setelah pemerintah menaikkan harga BBM dengan mengurangi subsidi BBM yang kemudian selisih subsidi tersebut diberikan kepada masyarakat miskin [1].

Dari kondisi tersebut, maka pemerintah membuat kebijakan ataupun program untuk menanggulangi masalah yang terjadi. Salah satunya yaitu program Bantuan Langsung Tunai (cash transfers) atau sering disingkat BLT adalah program bantuan pemerintah bejenis pemberian uang tunai atau berupa bantuan lainnya baik bersyarat (conditional cash transfer) maupun tidak bersyarat (unconditional cash transfer) untuk masyarakat miskin supaya dapat meningkatkan hidup yang lebih baik.

Hal ini membuat penulis tertarik untuk mencari tahu dan meneliti dengan menerapkan salah satu metode dari data mining yaitu naive bayes. Data Mining merupakan kegiatan mengumpulkan data dengan jumlah yang banyak lalu diekstrak menjadi informasi sehingga nantinya dapat digunakan. Sedangkan Naive Bayes adalah metode pembelajaran mesin yang memanfaatkan perhitungan probabilitas dan statistik yang dikemukakan oleh ilmuwan Inggris Thomas Bayes yaitu memprediksi probabilitas di masa depan berdasarkan pengalaman di masa sebelumnya. Kelebihan dari naive bayes yaitu mudah diimplementasikan, memerlukan jumlah data sedikit yang dibutuhkan untuk klasifikasi dan lebih cepat dalam perhitungan.

\section{Data Mining}

\section{STUDI LITERATUR}

Data mining juga merupakan salah satu bagian proses Knowledge Discovery from Databases (KDD) yang bertugas untuk mengekstarak pola atau model dari data dengan menggunakan suatu algoritma yang spesifik untuk mendapatkna hasil yang diinginkan [4] [6].

Data mining merupakan suatu proses ataupun kegiatan mengumpulkan data yang berukuran besar dengan menyatukan teknik dari pembelajaran mesin kemudian nantinya output dari data tersebut akan menjadi sebuah 
informasi yang selanjutnya dapat digunakan [3].

Berdasarkan hal tersebut data mining yang dikemukakan maka data mining adalah suatu tempat untuk memproses data yang jumlahnya tidak sedikit dan selanjutnya data tersebut dapat diolah dengan metode melalui perhitungan data dan pengklasifikasian data secara khusus dan hasil akhirnya akan menjadi sebuah informasi.

\section{Naive Bayes}

Naive Bayes memprediksi peluang di masa depan berdasarkan pengalaman di masa sebelumnya sehingga dikenal sebagai Teorema Bayes. Kelebihan dari naive bayes yaitu mudah diimplementasikan, lebih cepat dalam perhitungan dan memerlukan jumlah data sedikit yang dibutuhkan untuk klasifikasi. Karena yang diasumsikan sebagai variabel independent, maka hanya varian dari suatu variabel dalam sebuah kelas yang dibutuhkan untuk menentukan klasifikasi [4][8][9].

Persamaan dari teorama bayes

$$
P(H \mid X)=\frac{P(X \mid H) \cdot P(H)}{P(X)}
$$

Keterangan :

X : Data dengan class yang belum diketahui

$\mathrm{H} \quad$ : Hipotesis data merupakan suatu class spesifik

$\mathrm{P}(\mathrm{H} \mid \mathrm{X})$ : Probabilitas hipotesis $\mathrm{H}$ berdasarkan kondisi $\mathrm{X}$ (posteriori probabilitas)

$\mathrm{P}(\mathrm{H}) \quad$ : Probabilitas hipotesis $\mathrm{H}$ (prior probabilitas)

$\mathrm{P}(\mathrm{X} \mid \mathrm{H})$ : Probabilitas hipotesis $\mathrm{X}$ berdasarkan kondisi pada $\mathrm{H}$

$\mathrm{P}(\mathrm{X}) \quad$ : Probabilitas $\mathrm{X}$

Penjabaran lebih lanjut rumus Bayes tersebut dapat dilakukan dengan menjabarkan $(\mathrm{C} \mid \mathrm{X} 1 \ldots . . ., \mathrm{Xn})$ menggunakan aturan perkalian sebagai berikut.

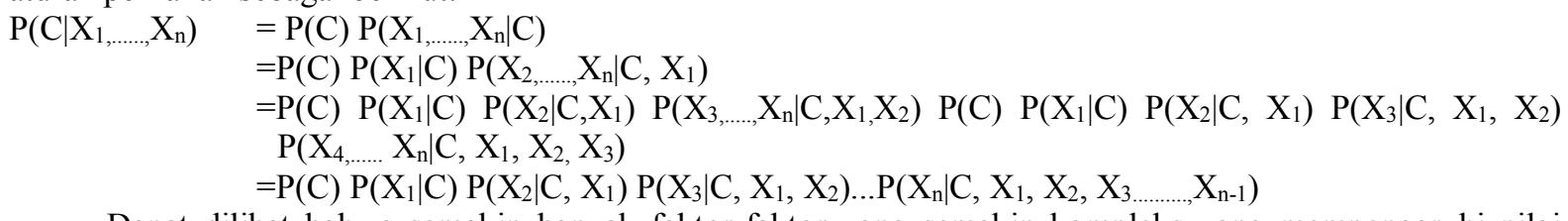
probabilitas, maka semakin mustahil untuk menghitung nilai tersebut satu persatu. Akibatnya perhitungan semakin sulit untuk dilakukan, maka disinilah digunakan asumsi independensi yang sangat tinggi, bahwa masingmasing atribut dapat saling bebas.

Untuk $i \neq j$, sehingga

$$
\begin{aligned}
\mathrm{P}\left(\mathrm{X}_{\mathrm{i}} \mid \mathrm{X}_{\mathrm{j}}\right)= & \frac{P\left(X_{i} \cap X_{j}\right)}{P\left(X_{j}\right)} \\
= & \frac{P\left(X_{i}\right) P\left(X_{j}\right)}{P\left(X_{j}\right)} \\
& =P\left(X_{i}\right)
\end{aligned}
$$

Dapat diambil kesimpulan bahwa asumsi independensi membuat syarat perhitungan menjadi sederhana. Selanjutnya penjabaran $\mathrm{P}\left(\mathrm{C} \mid \mathrm{X}_{1, \ldots . .,} \mathrm{X}_{\mathrm{n}}\right)$ dapat disederhanakan menjadi:

$\mathrm{P}\left(\mathrm{X}_{2} \mid \mathrm{C}\right) \mathrm{P}\left(\mathrm{X}_{3} \mid \mathrm{C}\right) \ldots$.

$$
\begin{aligned}
\mathrm{P}(\mathrm{C} \mid \mathrm{X} 1, \ldots, \mathrm{Xn}) & =\mathrm{P}\left(\mathrm{X}_{2} \mid \mathrm{C}\right) \\
& =\mathrm{P}(\mathrm{C}) \prod_{i=1}^{n} P(X i \mid C)
\end{aligned}
$$

Keterangan :

$\prod_{i=1}^{n} P(X i \mid C)=$ perkalian ranting antar atribut

Model dari teorama naive bayes yang selanjutnya akan digunakan dalam proses klasifikasi. Untuk klasifikasi dengan data kontinu atau data angka menggunakan rumus distribusi Gaussian 2 parameter: mean $\mu$ varian $\sigma$ :

$$
\mathrm{P}\left(\mathrm{X}_{1}=\mathrm{X}_{\mathrm{i}} \mid \mathrm{C}=\mathrm{c}_{\mathrm{j}}\right)=\frac{1}{\sqrt{2 \pi \sigma i j}} \exp \frac{(x i-\mu i j) 2}{2 \sigma 2 i j}
$$

Keterangan :

$\begin{array}{ll}\mathrm{P} & \text { : Peluang } \\ \mathrm{Xi} & \text { : Atribut ke } \mathrm{i} \\ \mathrm{Xj} & \text { : Nilai atribut ke } \mathrm{i} \\ \mathrm{C} & \text { : Kelas yang dicari } \\ \mathrm{Ci} & \text { : Sub kelas Y yang dicari }\end{array}$


$\mu \quad$ : Menyatakan rata-rata dari seluruh atribut

$\sigma \quad$ : Deviasi standar, menyatakan varian dari seluruh atribut

Dalam metode naive bayes diperlukan data latih dan data uji yang ingin diklasifikasikan dalam naive bayes. Semakin banyak data latih yang dilibatkan, maka semakin baik prediksi yang diberikan. Menghitung $\mathrm{P}(\mathrm{Ci})$ yang merupakan probabilitas prior untuk setiap kelas $\mathrm{C}$ yang akan dihasilkan menggunakan persamaan :

$$
\mathrm{P}(\mathrm{Ci})=\frac{s i}{s}
$$

Dimana si adalah jumlah data training dari kategori $\mathrm{Ci}$, dan s adalah jumlah total data training.

\section{Bantuan Langsung Tunai (BLT)}

Program Bantuan Langsung Tunai (BLT) adalah program bantuan pemerintah berjenis pemberian uang tunai atau beragam bantuan lainnya, baik bersyarat maupun tidak bersyarat untuk masyarakat miskin. Program Bantuan Langsung Tunai (BLT) dirancang sebagai pengganti biaya hidup ketika terjadi kenaikan harga BBM [1] [5]. Program penerima Bantuan Langsung Tunai (BLT) juga tidak sembarang dalam menentukan siapa yang layak menerima melainkan ada beberapa hal yang harus dipenuhi untuk menerima Bantuan Langsung Tunai (BLT).

Dalam hal pemberian Bantuan Langsung Tunai (BLT) ada persyaratan atau kriteria khusus. Adapun Kriteria dalam Pemilihan Penerima Bantuan Langsung Tunai (BLT) yaitu kepala rumah tangga, non PKH, non BPNT, kehilangan mata pencaharian, belum terdata, dan mempunyai anggota keluarga yang sakit kronis.

\section{METODE}

Kerangka kerja ini merupakan langkah-langkah yang akan dilakukan dalam penyelesaian masalah yang akan dibahas. Adapun kerangka kerja penelitian yang di gunakan seperti terlihat pada gambar 1:

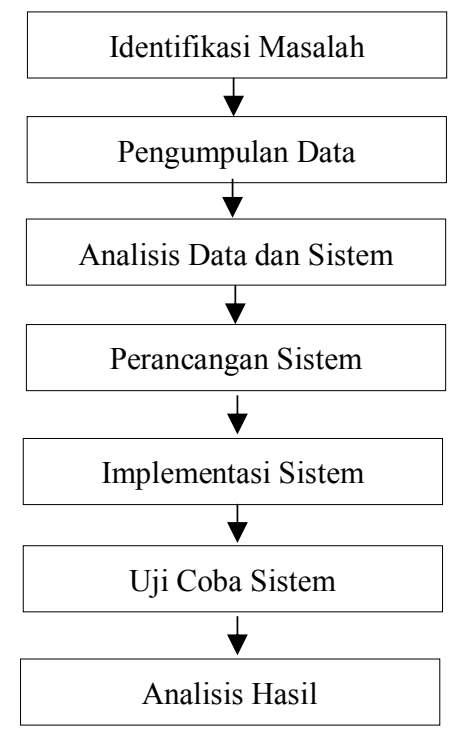

Gambar 1. Kerangka Kerja Penelitian

Berdasarkan kerangka kerja penelitian yang telah digambarkan di atas, maka dapat diuraikan pembahasan masing-masing tahap dalam penelitian adalah sebagai berikut:

1. Identifikasi Masalah

Identifikasi masalah disebut juga dengan problem identification adalah suatu proses dan hasil pengenalan masalah atau inventarisasi masalah dengan kata lain identifikasi masalah adalah salah satu proses penelitian yang bisa dikatakan langkah paling penting diantara langkah-langkah proses yang lain. Tujuan identifikasi masalah yaitu agar kita maupun pembaca mendapatkan sejumlah masalah yang berhubungan dengan judul penelitian.

2. Pengumpulan Data

Pengumpulan data adalah teknik atau cara yang dilakukan oleh peneliti untuk mengumpulkan data. Pengumpulan data dilakukan guna memperoleh informasi yang dibutuhkan dalam rangka mencapai tujuan penelitian. Adapun teknik pengumpulan data tersebut dilakukan dengan cara wawancara (interview) dan studi dokumentasi. Wawancara dilakukan untuk mewawancarai sumbernya dengan mengajukan beberapa pertanyaan yang berkaitan dengan penerima bantuan langsung tunai (BLT) di Kantor Kepala Desa Perkebunan Air Batu III/IX dan Kantor Kepala Desa Sei Alim Ulu. Selain itu, penulis juga melakukan studi dokumentasi untuk memperoleh informasi berupa dokumen yang berisi data penerima bantuan 
langsung tunai yang dibutuhkan dalam proses penelitian sehingga bertujuan menghasilkan informasi yang relevan.

3. Analisis Data dan Sistem

Pada tahap ini dilakukan identifikasi masalah pada sistem yang sedang berjalan. Dengan demikian, diharapkan peneliti dapat menemukan kendala-kendala dan permasalahan yang terjadi pada penerima bantuan langsung tunai (BLT) di Kantor Kepala Desa Perkebunan Air Batu III/IX dan Kantor Kepala Desa Sei Alim Ulu. Sehingga peneliti dapat mencari solusi dari permasalahan tersebut.

4. Perancangan Sistem

Perancangan sistem adalah sebuah kegiatan menentukan cara mengolah sistem informasi dari hasil analisa sistem sehingga dapat memenuhi kebutuhan dari pengguna termasuk diantaranya perancangan user interface dan aktivitas-aktivitas proses. Adapun proses perancangan suatu sistem informasi dilakukan dengan megamati aliran sistem informasi yang sedang berjalan serta membuat suatu sistem informasi baru yang telah didesain dengan alat bantu perancangan yaitu unified modelling language (UML).

5. Implementasi Sistem

Implementasi sistem adalah prosedur yang dilakukan untuk menyelesaikan desain yang ada dalam dokumen yaitu desain sistem yang disetujui dan menguji, menginstal, memulai, serta menggunakan sistem yang baru atau sistem yang diperbaiki.

6. Uji Coba Sistem

Uji coba sistem yaitu proses yang dilakukan untuk menilai apakah sistem yang dibuat telah sesuai dengan apa yang diharapkan, merupakan suatu kegiatan guna mengevaluasi keunggulan dan kelemahan terhadap sistem. Setelah sistem dibangun berdasarkan yang dirancang oleh penulis, maka penulis melakukan uji coba untuk mengevaluasi keunggulan dan kelemahan dari sistem yang telah dibangun.

7. Analisis Hasil

Analisis Hasil adalah prosedur yang dilakukan untuk memberikan kesimpulan dari hasil implementasi sistem yang sudah dilakukan, apakah sistem yang dibuat sudah layak di pergunakan.

\section{HASIL}

Analisis data yaitu upaya/cara untuk mengelolah data menjadi informasi sehingga karakteristik data tersebut bisa dipahami dan bermanfaat untuk solusi permasalahan, terutama masalah yang berkaitan dengan penelitian. Dalam masalah penelitian ini, data yang digunakan sebagai dasar analisis adalah data penerima Bantuan Langsung Tunai di tahun sebelumnya. Datanya ada 123 bisa dilihat pada tabel 1 berikut:

Tabel 1 Data Latih

\begin{tabular}{|c|c|c|c|c|c|c|c|c|}
\hline No & Nama Lengkap & $\begin{array}{l}\text { Kepala } \\
\text { Rumah } \\
\text { Tangga }\end{array}$ & $\mathrm{PKH}$ & BPNT & $\begin{array}{l}\text { Kehilangan } \\
\text { Pencaharian }\end{array}$ & $\begin{array}{c}\text { Tidak } \\
\text { Terdata }\end{array}$ & $\begin{array}{c}\text { Anggota } \\
\text { Keluarga } \\
\text { Sakit } \\
\text { Kronis }\end{array}$ & Status \\
\hline 1 & Samiyem & Perempuan & Non & Non & Tidak & Terdata & Tidak & Layak \\
\hline 2 & Sri Mariyati & Perempuan & Non & Non & Tidak & Terdata & Tidak & Layak \\
\hline 3 & Dedi Arianto & Laki-Laki & Non & Ya & Tidak & Terdata & Tidak & Tidak Layak \\
\hline 4 & Saepuddin & Laki-Laki & Non & $\mathrm{Ya}$ & Tidak & Terdata & Tidak & Tidak Layak \\
\hline 5 & Junaedi & Laki-Laki & Ya & Non & Tidak & Terdata & Tidak & Tidak Layak \\
\hline 6 & Jumirah & Perempuan & Non & Non & Tidak & Terdata & Tidak & Layak \\
\hline 7 & Marnisari & Perempuan & Ya & Ya & Tidak & Terdata & Tidak & Tidak Layak \\
\hline 8 & Hidayat & Laki-Laki & Non & Non & $\mathrm{Ya}$ & Terdata & Tidak & Layak \\
\hline 9 & Yuliana & Perempuan & Non & Non & $\mathrm{Ya}$ & Terdata & Tidak & Layak \\
\hline 10 & Zainal Abidin & Laki-Laki & Non & Non & $\mathrm{Ya}$ & Terdata & Tidak & Layak \\
\hline
\end{tabular}

Sumber: data kantor desa Perkebunan Air Batu III/IX dan kantor desa Sei Alim Ulu Keterangan :

- Kriteria Kepala Keluarga : Merupakan variabel yang akan dikelompokkan menjadi 2 kategori yaitu lakilaki dan perempuan. Kepala rumah tangga perempuan dikarenakan suami atau kepala rumah tangga lakilaki telah meninggal.

- $\quad$ Kriteria PKH : Status PKH di kategorikan menjadi 2 yaitu penerima PKH (ya) dan tidak penerima PKH (non). 
- $\quad$ Kriteria BPNT : Merupakan program yang memberikan bantuan sosial pangan dalam bentuk non tunai, jika memenuhi persyaratan ini maka kemungkinan layak menerima BLT. Pada kasus ini status BPNT dikategorikan menjadi 2 yaitu penerima BPNT (ya) dan tidak penerima BPNT (non).

- Kriteria Kehilangan Pencaharian : Yaitu kehilangan mata pencaharian karena terdampak covid dan tidak memiliki cadangan ekonomi yang cukup untuk bertahan hidup selama tiga bulan ke depan. Pada kasus ini status Kehilangan Pencaharian dikategorikan menjadi 2 yaitu penerima

- Kehilangan Pencaharian (ya) dan tidak penerima Kehilangan Pencaharian (tidak).

- Kriteria Tidak Terdata : Pada kasus ini penerima (Terdata) dan tidak penerima (Tidak Terdata).

- Kriteria Anggota Keluarga Sakit Kronis: Yaitu anggota keluarga sakit kronis seperti darah tinggi, ginjal, dan jantung. Pada kasus ini status anggota keluarga sakit kronis dikategorikan menjadi 2 yaitu penerima (ya) dan tidak penerima (tidak).

\section{Menghitung Jumlah Class/Kelas (P(Ci))}

Ada 123 data latih yang digunakan, didalamnya diketahui kelas Tidak Layak (C0) sebanyak 51 data dan Kelas Layak (C1) sebanyak 72 data. Perhitungan probabilitas prior kemungkinan tidak layak penerima Bantuan Langsung Tunai (BLT).

$$
\mathrm{P}(\mathrm{C} 0)=\frac{51}{123}=0,4146
$$

Sedangkan perhitungan probabilitas kemungkinan layak yaitu:

$$
\mathrm{P}(\mathrm{C} 1)=\frac{72}{123}=0,5854
$$

\section{Menghitung Jumlah Kasus yang sama dengan Class yang sama} dibawah:

Untuk menghitung kemungkinana hasil kriteria P(Kepala Rumah Tangga|Ci) bisa dilihat pada tabel 2

Tabel 2 Probabilitas Kepala Rumah Tangga

\begin{tabular}{lllll}
\hline \hline $\begin{array}{l}\text { Kepala Rumah } \\
\text { Tangga }\end{array}$ & \multicolumn{3}{c}{ Jumlah Keadian } & Probabilitas \\
\hline & Layak & Tidak Layak & Layak (C1) & Tidak Layak (C0) \\
Laki-laki & 46 & 47 & 0,6389 & 0,9216 \\
Perempuan & 26 & 4 & 0,3611 & 0,0784 \\
\hline Jumlah & 72 & 51 & 1 & 1 \\
\hline
\end{tabular}

Untuk menghitung kemungkinana halil kriteria $\mathrm{P}(\mathrm{Status} \mathrm{PKH} \mid \mathrm{Ci})$ bisa dilihat pada tabel 3 dibawah:

Tabel 3 Probabilitas Status PKH

\begin{tabular}{lllll}
\hline PKH & \multicolumn{3}{c}{ Jumlah Kejadian Dipilih } & Probabilitas \\
\hline & Layak & Tidak Layak & Layak (C1) & Tidak Layak (C0) \\
Non & 64 & 32 & 0,8889 & 0,6275 \\
Ya & 8 & 19 & 0,1111 & 0,3725 \\
\hline Jumlah & 72 & 51 & 1 & 1 \\
\hline
\end{tabular}

Untuk menghitung kemungkinana halil kriteria $\mathrm{P}($ Status $\mathrm{BPNT} \mid \mathrm{Ci})$ bisa dilihat pada tabel 4 dibawah:

\begin{tabular}{|c|c|c|c|c|}
\hline \multirow[t]{2}{*}{ BNPT } & \multicolumn{2}{|c|}{ Jumlah Kejadian Dipilih } & \multicolumn{2}{|c|}{ Probabilitas } \\
\hline & Layak & Tidak Layak & Layak (C1) & Tidak Layak (C0) \\
\hline Non & 69 & 9 & 0,9583 & 0,1765 \\
\hline $\mathrm{Ya}$ & 3 & 52 & 0,0417 & 0,8235 \\
\hline Jumlah & 72 & 51 & 1 & 1 \\
\hline
\end{tabular}

Tabel 4 Probabilitas Status BPNT

Untuk menghitung kemungkinana halil kriteria P(Status Kehilangan Pencaharian|Ci) bisa dilihat pada tabel 5 dibawah: 
Tabel 5 Probabilitas Kehilangan Pencaharian

\begin{tabular}{|c|c|c|c|c|}
\hline \multirow{2}{*}{$\begin{array}{l}\text { Kehilangan } \\
\text { Pencarian }\end{array}$} & \multicolumn{2}{|c|}{ Jumlah Kejadian Dipilih } & \multicolumn{2}{|c|}{ Probabilitas } \\
\hline & Layak & Tidak Layak & Layak (C1) & Tidak Layak (C0) \\
\hline Ya & 35 & 3 & 0,4861 & 0,0588 \\
\hline Tidak & 37 & 48 & 0,5139 & 0,94412 \\
\hline Jumlah & 72 & 51 & 1 & 1 \\
\hline
\end{tabular}

Untuk menghitung kemungkinana halil kriteria $\mathrm{P}($ Status Tidak Terdata|Ci) bisa dilihat pada tabel 6 dibawah:

Tabel 6 Probabilitas Tidak Terdata

\begin{tabular}{lllll}
\hline Tidak Terdata & \multicolumn{3}{c}{ Jumlah Kejadian Dipilih } & Probabilitas \\
\hline & Layak & Tidak Layak & Layak (C1) & Tidak Layak (C0) \\
Terdata & 70 & 51 & 0,9722 & 1,0000 \\
Tidak Terdata & 2 & 0 & 0,0278 & 0,0000 \\
\hline Jumlah & 72 & 51 & 1 & 1 \\
\hline
\end{tabular}

Untuk menghitung kemungkinana halil kriteria P(Status Anggota Keluarga Sakit Kronis $\mid \mathrm{Ci}$ ) bisa dilihat pada tabel 7 dibawah:

Tabel 7 Probabilitas Anggota Keluarga Sakit Kronis

\begin{tabular}{lllll}
\hline \hline Anggota Keluarga & \multicolumn{3}{c}{ Jumlah Kejadian Dipilih } & Probabilitas \\
Sakit Kronis & & & Layak (C1) & Tidak Layak (C0) \\
\hline & Layak & Tidak Layak & 0,9583 & 0,9608 \\
Tidak & 69 & 49 & 0,0417 & 0,0392 \\
Ya & 3 & 2 & 1 & 1 \\
\hline Jumlah & 72 & 51 & \\
\hline
\end{tabular}

\section{Perhitungan Manual}

Perhitungan manual dengan menggunakan 5 data uji untuk mengetahui status penerima layak atau tidak layak dapat diliihat pada tabel 8 dengan menggunakan naive bayes.

Tabel 8 Data Uji

\begin{tabular}{|c|c|c|c|c|c|c|c|c|}
\hline No & Nama Lengkap & $\begin{array}{l}\text { Kepala } \\
\text { Rumah } \\
\text { Tangga }\end{array}$ & PKH & BPNT & $\begin{array}{l}\text { Kehilangan } \\
\text { Pencaharian }\end{array}$ & $\begin{array}{c}\text { Tidak } \\
\text { Terdata }\end{array}$ & $\begin{array}{c}\text { Anggota } \\
\text { Keluarga } \\
\text { Sakit } \\
\text { Kronis }\end{array}$ & Status \\
\hline 1 & Anto & Laki-Laki & ya & ya & tidak & Terdata & tidak & ? \\
\hline 2 & Samiran & Laki-Laki & non & non & ya & Terdata & tidak & $?$ \\
\hline 3 & Jemirah & Perempuan & ya & non & ya & Terdata & tidak & $?$ \\
\hline 4 & Miranto & Laki-Laki & non & ya & tidak & Terdata & tidak & ? \\
\hline 5 & Misdi & Laki-Laki & non & ya & ya & Terdata & tidak & $?$ \\
\hline
\end{tabular}

\section{Kalikan Semua Variabel Layak dan Tidak Layak}

1. Dari tabel 4.9 dapat dilakukan klasifikasi kedalam kelas layak (C1) penerima BLT dengan ketentuan nilai masing-masing kriteria tersebut dikalikan Layak $(\mathrm{C} 1)=\mathrm{P}($ Kepala Rumah Tangga=Laki-Laki $\mid \mathrm{C} 1)$ * $\mathrm{P}(\mathrm{Status}$ $\mathrm{PKH}=\mathrm{ya} \mid \mathrm{C} 1) * \mathrm{P}($ Status BPNT=ya $\mid \mathrm{C} 1) * \mathrm{P}($ Kehilangan Pencaharian=tidak $\mid \mathrm{C} 1) * \mathrm{P}($ Tidak Terdata=terdata $\mid \mathrm{C} 1) *$ $\mathrm{P}($ Anggota Keluarga Sakit Kronis=tidak $\mid \mathrm{C} 1) * \mathrm{P}(\mathrm{C} 1)$

$$
\begin{aligned}
& =0,6389 * 0,1111 * 0,0417 * 0,5139 * 0,9722 * 0,9583 * 0,5854 \\
& =0,000829
\end{aligned}
$$

Tidak Layak $(\mathrm{C} 0)=\mathrm{P}($ Kepala Rumah Tangga $=$ Laki-Laki $\mid \mathrm{C} 0) * \mathrm{P}($ Status $\mathrm{PKH}=\mathrm{ya} \mid \mathrm{C} 0) * \mathrm{P}(\mathrm{Status} \mathrm{BPNT}=\mathrm{ya} \mid \mathrm{C} 0) *$ $\mathrm{P}($ Kehilangan Pencaharian=tidak $\mid \mathrm{C} 0) \quad * \quad \mathrm{P}($ Tidak Terdata=terdata $\mid \mathrm{C} 0) \quad * \quad \mathrm{P}($ Anggota Keluarga Sakit 
Kronis $=$ tidak $\mid \mathrm{C} 0) * \mathrm{P}(\mathrm{C} 0)$

$$
\begin{aligned}
& =0,9216 * 0,3725 * 0,8235 * 0,9412 * 1 * 0,9608 * 0,4146 \\
& =0,106011
\end{aligned}
$$

2. Dari tabel 4.9 dapat dilakukan klasifikasi kedalam kelas layak (C1) penerima BLT dengan ketentuan nilai masing-masing kriteria tersebut dikalikan Layak $(\mathrm{C} 1)=\mathrm{P}($ Kepala Rumah Tangga=Laki-Laki $\mid \mathrm{C} 1) * \mathrm{P}($ Status $\mathrm{PKH}=$ non $\mid \mathrm{C} 1) * \mathrm{P}($ Status BPNT=non $\mid \mathrm{C} 1) * \mathrm{P}($ Kehilangan Pencaharian=ya $\mid \mathrm{C} 1) * \mathrm{P}($ Tidak Terdata=terdata $\mid \mathrm{C} 1)$ * $\mathrm{P}($ Anggota Keluarga Sakit Kronis=tidak $\mid \mathrm{C} 1) * \mathrm{P}(\mathrm{C} 1)$

$$
\begin{aligned}
& =0,6389 * 0,8889 * 0,9583 * 0,4861 * 0,9722 * 0,9583 * 0,5854 \\
& =0,144289
\end{aligned}
$$

Tidak Layak $(\mathrm{C} 0)=\mathrm{P}($ Kepala Rumah Tangga $=$ Laki-Laki $\mid \mathrm{C} 0) * \mathrm{P}($ Status $\mathrm{PKH}=$ non $\mid \mathrm{C} 0) * \mathrm{P}($ Status BPNT=non $\mid \mathrm{C} 0)$ * $\mathrm{P}($ Kehilangan Pencaharian=ya $\mid \mathrm{C} 0) * \mathrm{P}($ Tidak Terdata $=$ terdata $\mid \mathrm{C} 0) * \mathrm{P}($ Anggota Keluarga Sakit Kronis=tidak $\mid \mathrm{C} 0)$ * $\mathrm{P}(\mathrm{C} 0)$

$$
=0,9216 * 0,6275 * 0,1765 * 0,0588 * 1 * 0,9608 * 0,4146
$$

$=0,002391$

3. Dari tabel 4.9 dapat dilakukan klasifikasi kedalam kelas layak (C1) penerima BLT dengan ketentuan nilai masing-masing kriteria tersebut dikalikan Layak $(\mathrm{C} 1)=\mathrm{P}($ Kepala Rumah Tangga $=$ Perempuan $\mid \mathrm{C} 1) * \mathrm{P}($ Status $\mathrm{PKH}=\mathrm{ya} \mid \mathrm{C} 1) * \mathrm{P}($ Status BPNT=non $\mid \mathrm{C} 1) * \mathrm{P}($ Kehilangan Pencaharian=ya $\mid \mathrm{C} 1) * \mathrm{P}($ Tidak Terdata=terdata $\mid \mathrm{C} 1)$ * $\mathrm{P}($ Anggota Keluarga Sakit Kronis=tidak $\mid \mathrm{C} 1) * \mathrm{P}(\mathrm{C} 1)$

$$
\begin{aligned}
& =0,3611 * 0,1111 * 0,9583 * 0,4861 * 0,9722 * 0,9583 * 0,5854 \\
& =0,010194
\end{aligned}
$$

Tidak Layak $(\mathrm{C} 0)=\mathrm{P}($ Kepala Rumah Tangga $=$ Perempuan $\mid \mathrm{C} 0) * \mathrm{P}($ Status $\mathrm{PKH}=\mathrm{ya} \mid \mathrm{C} 0) * \mathrm{P}($ Status BPNT=non $\mid \mathrm{C} 0)$ * $\mathrm{P}($ Kehilangan $\mathrm{Pencaharian}=\mathrm{ya} \mid \mathrm{C} 0)$ * $\mathrm{P}($ Tidak Terdata=terdata $\mid \mathrm{C} 0) * \mathrm{P}($ Anggota Keluarga Sakit Kronis $=$ tidak $\mid \mathrm{C} 0) * \mathrm{P}(\mathrm{C} 0)$

$$
\begin{aligned}
& =0,0784 * 0,3725 * 0,1765 * 0,0588 * 1 * 0,9608 * 0,4146 \\
& =0,000121
\end{aligned}
$$

4. Dari tabel 4.9 dapat dilakukan klasifikasi kedalam kelas layak (C1) penerima BLT dengan ketentuan nilai masing-masing kriteria tersebut dikalikan Layak $(\mathrm{C} 1)=\mathrm{P}($ Kepala Rumah Tangga=Laki-Laki $\mid \mathrm{C} 1) * \mathrm{P}($ Status $\mathrm{PKH}=$ non $\mid \mathrm{C} 1) * \mathrm{P}($ Status BPNT=ya $\mid \mathrm{C} 1) * \mathrm{P}($ Kehilangan Pencaharian=tidak $\mid \mathrm{C} 1) * \mathrm{P}($ Tidak Terdata=terdata $\mid \mathrm{C} 1)$ * P(Anggota Keluarga Sakit Kronis=tidak $\mid \mathrm{C} 1) * \mathrm{P}(\mathrm{C} 1)$

$$
\begin{aligned}
& =0,6389 * 0,8889 * 0,0417 * 0,5139 * 0,9722 * 0,9583 * 0,5854 \\
& =0,006632
\end{aligned}
$$

Tidak Layak $(\mathrm{C} 0)=\mathrm{P}($ Kepala Rumah Tangga $=$ Laki-Laki $\mid \mathrm{C} 0) * \mathrm{P}($ Status $\mathrm{PKH}=$ non $\mid \mathrm{C} 0) * \mathrm{P}($ Status BPNT $=\mathrm{ya} \mid \mathrm{C} 0)$ * $\mathrm{P}($ Kehilangan Pencaharian=tidak $\mid \mathrm{C} 0) * \mathrm{P}($ Tidak Terdata=terdata $\mid \mathrm{C} 0) * \mathrm{P}($ Anggota Keluarga Sakit Kronis $=$ tidak $\mid \mathrm{C} 0) * \mathrm{P}(\mathrm{C} 0)$

$$
\begin{aligned}
& =0,9216 * 0,6275 * 0,8235 * 0,0588 * 1 * 0,9608 * 0,4146 \\
& =0,178545
\end{aligned}
$$

5. Dari tabel 4.9 dapat dilakukan klasifikasi kedalam kelas layak (C1) penerima BLT dengan ketentuan nilai masing-masing kriteria tersebut dikalikan Layak $(\mathrm{C} 1)=\mathrm{P}($ Kepala Rumah Tangga=Laki-Laki $\mid \mathrm{C} 1)$ * $\mathrm{P}($ Status $\mathrm{PKH}=$ non $\mid \mathrm{C} 1) * \mathrm{P}($ Status BPNT=ya $\mid \mathrm{C} 1) * \mathrm{P}($ Kehilangan Pencaharian=ya $\mid \mathrm{C} 1)$ * $\mathrm{P}($ Tidak Terdata=terdata $\mid \mathrm{C} 1)$ * $\mathrm{P}($ Anggota Keluarga Sakit Kronis=tidak $\mid \mathrm{C} 1) * \mathrm{P}(\mathrm{C} 1)$

$$
\begin{aligned}
& =0,6389 * 0,8889 * 0,0417 * 0,4861 * 1 * 0,9583 * 0,5859 \\
& =0,006273
\end{aligned}
$$

Tidak Layak $(\mathrm{C} 0)=\mathrm{P}($ Kepala Rumah Tangga $=$ Laki-Laki $\mid \mathrm{C} 0) * \mathrm{P}($ Status $\mathrm{PKH}=$ non $\mid \mathrm{C} 0) * \mathrm{P}($ Status BPNT=ya $\mid \mathrm{C} 0)$ * $\mathrm{P}($ Kehilangan Pencaharian=ya $\mid \mathrm{C} 0)$ *

$\mathrm{P}($ Tidak Terdata=terdata $\mid \mathrm{C} 0) * \mathrm{P}($ Anggota Keluarga Sakit Kronis $=$ tidak $\mid \mathrm{C} 0) * \mathrm{P}(\mathrm{C} 0)$ $=0,9216 * 0,6275 * 0,8235 * 0,0588 * 1 * 0,9608 * 0,4146$ 


$$
=0,011159
$$

\section{Bandingkan Hasil Perkelas}

1. Dari perhitungan diatas untuk data uji yang pertama dihasilkan nilai $\mathrm{P}(\mathrm{C} 1 \mid \mathrm{X})=0,000829$ sedangkan nilai $\mathrm{P}(\mathrm{C} 0 \mid \mathrm{X})=0,106011$. Dapat disimpulkan bahwa $\mathrm{P}(\mathrm{C} 0 \mid \mathrm{X})>\mathrm{P}(\mathrm{C} 1 \mid \mathrm{X})$ maka data uji tersebut diklasifikasikan kedalam kelas Tidak Layak dalam menerima BLT.

2. Dari perhitungan diatas untuk data uji yang kedua dihasilkan nilai $\mathrm{P}(\mathrm{C} 1 \mid \mathrm{X})=0,144298$ sedangkan nilai $\mathrm{P}(\mathrm{C} 0 \mid \mathrm{X})=0,002391$. Dapat disimpulkan bahwa $\mathrm{P}(\mathrm{C} 1 \mid \mathrm{X})>\mathrm{P}(\mathrm{C} 0 \mid \mathrm{X})$ maka data uji tersebut diklasifikasikan kedalam kelas Layak dalam menerima BLT.

3. Dari perhitungan diatas untuk data uji yang ketiga dihasilkan nilai $\mathrm{P}(\mathrm{C} 1 \mid \mathrm{X})=0,010194$ sedangkan nilai $\mathrm{P}(\mathrm{C} 0 \mid \mathrm{X})=0,000121$. Dapat disimpulkan bahwa $\mathrm{P}(\mathrm{C} 1 \mid \mathrm{X})>\mathrm{P}(\mathrm{C} 0 \mid \mathrm{X})$ maka data uji tersebut diklasifikasikan kedalam kelas Layak dalam menerima BLT.

4. Dari perhitungan diatas untuk data uji yang kedua dihasilkan nilai $\mathrm{P}(\mathrm{C} 1 \mid \mathrm{X})=0,006632$ sedangkan nilai $\mathrm{P}(\mathrm{C} 0 \mid \mathrm{X})=0,178545$. Dapat disimpulkan bahwa $\mathrm{P}(\mathrm{C} 0 \mid \mathrm{X})>\mathrm{P}(\mathrm{C} 1 \mid \mathrm{X})$ maka data uji tersebut diklasifikasikan kedalam kelas Tidak Layak dalam menerima BLT.

5. Dari perhitungan diatas untuk data uji yang kedua dihasilkan nilai $\mathrm{P}(\mathrm{C} 1 \mid \mathrm{X})=0,006273$ sedangkan nilai $\mathrm{P}(\mathrm{C} 0 \mid \mathrm{X})=0,011159$. Dapat disimpulkan bahwa $\mathrm{P}(\mathrm{C} 0 \mid \mathrm{X})>\mathrm{P}(\mathrm{C} 1 \mid \mathrm{X})$ maka data uji tersebut diklasifikasikan kedalam kelas Tidak Layak dalam menerima BLT.

Kemudian, menghitung Akurasi yaitu: Jumlah prediksi benar/Jumlah data uji * 100\%. Dan menghitung Error yaitu: Jumlah prediksi salah/Jumlah data uji $* 100 \%$.

\section{KESIMPULAN}

1. Sistem Pemilihan calon penerima Bantuan Langsung Tunai menggunakan metode naive bayes, sehingga hasil dari penilaian yang telah dilakukan memiliki langkah-langkah dalam prosesnya adalah menghitung jumlah kelas/label, menghitung jumlah kasus perkelas, lalu mengalikan semua variabel kelas serta bandingkan hasil perkelas untuk mendapatkan nilai yang paling tertinggi. Untuk mendapatkan nilai tertinggi maka perlu dibandingkan hasil dari perkalian kelas layak dan tidak layak.

2. Sistem dirancang untuk solusi bagi Kantor Kepala Desa Perkebunan Air Batu III/IX dan Kantor Kepala Desa Sei Alim Ulu agar mempermudah pihak desa dalam proses pemilihan calon penerima Bantuan Langsung Tunai.

3. Metode naive bayes sangat cocok digunakan dalam memprediksi peluang dimasa depan berdasarkan pengalaman dimasa sebelumnya sehingga memudahkan perangkat desa dalam menentukan keluarga yang berhak menerima Bantuan Langsung Tunai.

\section{REFERENSI}

[1] A. S. R. Sinaga, M. Marbun, and A. S. Sitio, "Penerapan Teknologi Informasi Penentuan Prioritas Penerima Bantuan Langsung Tunai (BLT) desa Pagar Jati,” Jurdimas (Jurnal Pengabdi. Kpd. Masyarakat) $R$. , vol. 4, no. 1, pp. 65-70, 2021, doi: 10.33330/jurdimas.v4i1.681.

[2] A. Saleh, "Implementasi Metode Klasifikasi Naïve Bayes Dalam Memprediksi Besarnya Penggunaan Listrik Rumah Tangga," Creat. Inf. Technol. J., vol. 2, no. 3, pp. 207-217, 2015.

[3] C. Fadlan, S. Ningsih, and A. P. Windarto, "Penerapan Metode Naïve Bayes Dalam Klasifikasi Kelayakan Keluarga Penerima Beras Rastra," J. Tek. Inform. Musirawas, vol. 3, no. 1, p. 1, 2018, doi: 10.32767/jutim.v3i1.286.

[4] D. Jollyta, W. Ramdhan, and M. Zarlis, Konsep Data Mining dan Penerapan, Pertama. Yogyakarta: Deepublish, 2020.

[5] I. Akib and R. Risfaisal, "Bantuan Langsung Tunai," Equilib. J. Pendidik., vol. 3, no. 2, pp. 126-135, 2017, doi: 10.26618/equilibrium.v3i2.283.

[6] M. A. Sembiring, "Penerapan Metode Decision Tree Algoritma C45 Untuk Memprediksi Hasil Belajar Mahasiswa Berdasarkan Riwayat Akademik," J. Teknol. dan Sist. Inf., vol. 3, no. 1, pp. 60-65, 2016.

[7] M. Bolung and H. R. K. Tampangela, "Analisa Penggunaan Metodologi Pengembangan Perangkat Lunak,” J. ELTIKOM, vol. 1, no. 1, pp. 1-10, 2017, doi: 10.31961/eltikom.v1i1.1.

[8] H. Annur, "Klasifikasi Masyarakat Miskin Menggunakan Metode Naive Bayes," Ilk. J. Ilm., vol. 10, no. 2, pp. 160-165, 2018, doi: 10.33096/ilkom.v10i2.303.160-165.

[9] S. Syarli and A. Muin, "Metode Naive Bayes Untuk Prediksi Kelulusan (Studi Kasus: Data Mahasiswa Baru Perguruan Tinggi)," J. Ilm. Ilmu Komput., vol. 2, no. 1, pp. 22-26, 2016.

[10] Y. ZAKARIYA, "Implementasi Metode Naive Bayes Dalam Penentuan Kelayakan Penerima Bantuan Siswa Miskin,” Simki-Techsin, vol. 01, no. 01, pp. 1-7, 2017. 